by Philip L. Gibbard', Andrew M. Bauer ${ }^{2}$, Matthew Edgeworth ${ }^{3}$, William F. Ruddiman 4 , Jacquelyn L. Gill ${ }^{5}$, Dorothy J. Merritts ${ }^{6}$, Stanley C. Finney ${ }^{7}$, Lucy E. Edwards ${ }^{8}$, Michael J. C. Walker ${ }^{9}$, Mark Maslin ${ }^{10,11}$, and Erle C. Ellis ${ }^{12}$

\title{
A practical solution: the Anthropocene is a geological event, not a formal epoch
}

\author{
${ }^{1}$ Scott Polar Research Institute, University of Cambridge, Cambridge, CB2 1ER, UK \\ ${ }^{2}$ Department of Anthropology, Stanford University, Stanford, CA 94305, USA; *Corresponding author, E-mail: ambauer@stanford.edu \\ ${ }^{3}$ School of Archaeology and Ancient History, University of Leicester, Leicester LE1 7RH, UK \\ ${ }^{4}$ Department of Environmental Sciences, University of Virginia, Charlottesville, VA 22904, USA \\ ${ }^{5}$ Climate Change Institute and School of Biology and Ecology, University of Maine, Orono, ME 04469, USA \\ ${ }^{6}$ Department of Earth and Environment, Franklin and Marshall College, Post Office Box 3003, Lancaster, PA 17604, USA \\ ${ }^{7}$ Department of Geological Sciences, California State University, Long Beach, California 90840, USA \\ ${ }^{8}$ Florence Bascom Geoscience Center, U.S. Geological Survey, Reston, Virginia 20192, USA \\ ${ }^{9}$ Department of Geography and Earth Sciences, Aberystwyth University, Aberystwyth, Wales, SY23 3FL, UK \\ ${ }^{10}$ Department of Geography, University College London, Gower Street, London, WC1E 6BT, UK \\ ${ }^{11}$ Natural History Museum of Denmark, University of Copenhagen, Gothersgade 130, 1123 København K, Denmark \\ ${ }^{12}$ Department of Geography and Environmental Systems, University of Maryland, Baltimore County, Baltimore, Maryland 21250, USA
}

(Received: July 6, 2021; Revised accepted: October 4, 2021)

https://doi.org/10.18814/epiiugs/2021/021029

The Anthropocene has yet to be defined in a way that is functional both to the international geological community and to the broader fields of environmental and social sciences. Formally defining the Anthropocene as a chronostratigraphical series and geochronological epoch with a precise global start date would drastically reduce the Anthropocene's utility across disciplines. Instead, we propose the Anthropocene be defined as a geological event, thereby facilitating a robust geological definition linked with a scholarly framework more useful to and congruent with the many disciplines engaging with human-environment interactions. Unlike formal epochal definitions, geological events can recognize the spatial and temporal heterogeneity and diverse social and environmental processes that interact to produce anthropogenic global environmental changes. Consequently, an Anthropocene Event would incorporate a far broader range of transformative human cultural practices and would be more readily applicable across academic fields than an Anthropocene Epoch, while still enabling a robust stratigraphic characterization.

\section{Introduction}

The Anthropocene concept has been taken up in a variety of ways across many academic fields since it was first suggested approximately two decades ago (Crutzen and Stoermer, 2000; Crutzen, 2002; Revkin, 2016; Zalasiewicz et al., 2021). In the most general sense, it has been used as a way of characterizing the impact of human activity on Earth's environments and in transforming the Earth system. While this usage has helped to stimulate productive discussions across disciplines and raised public awareness of the effects of human activities on Earth's environmental systems, it also embeds and obscures a spectrum of conflicting scientific meanings and agendas (Finney and Edwards, 2016; Lorimer, 2017; Bauer and Ellis, 2018). Without an agreed definition, there will continue to be ambiguity within multiple scientific disciplines about the term's meaning and application, potentially leading to confusion among more general audiences as well.

One way to resolve this problem is to establish formally an Anthropocene Series/Epoch as a chronostratigraphic/geochronologic division in the International Geologic Time Scale (GTS). The Anthropocene Working Group (AWG) of the Subcommission on Quaternary Stratigraphy (SQS of the International Commission on Stratigraphy [ICS]) is in the process of preparing a proposal to establish the Anthropocene as a new chronostratigraphic series and corresponding epoch of time within the GTS, which may be formally adopted if its stratigraphic basis and utility for geoscientists can be demonstrated. A wide range of start dates for the Anthropocene Epoch have been proposed, including during the Pleistocene (Doughty et al., 2010), the Pleistocene-Holocene boundary (Smith and Zeder, 2013), 5020 BP (Lewis and Maslin, 2015), 3000 BP (Wagreich and Draganits, 2018), c. 2000 BP (Certini and Scalenghe, 2011), 1610, 1760, 1945 and 1964 (Lewis and Maslin, 2015) (Fig. 1). It now seems likely that the proposal of the AWG will equate the Anthropocene's onset with the 'Great Acceleration' following the Second World War in the mid- $20^{\text {th }}$ century. This coincides with changes deemed sufficient to leave a global stratigraphic signature of human impact distinct from that of the Holocene Series/Epoch or previous 
Pleistocene interglacial episodes (Zalasiewicz et al., 2015; Waters et al., 2016; Syvitski et al., 2020).

However, many scholars from within and beyond the geosciences have pointed to considerable problems that arise in attempting to define and formalize an Anthropocene Series/Epoch. Earth and environmental scientists have questioned the validity and utility of a chronostratigraphic/geochronologic definition (e.g., Finney and Edwards, 2016; Ruddiman, 2018; Edgeworth et al., 2019; Walker et al., 2019), while social science and humanities perspectives have challenged the ways human activities and historical processes are understood and incorporated within such a geological classification (e.g., Malm and Hornborg, 2014; Bauer and Bhan, 2018; Bauer and Ellis, 2018; Yusoff, 2018). Yet even with these valid critiques, many acknowledge that formal recognition of the significant effects of humans on Earth's surface processes and systemic functioning, and of their manifestations in the geological record, would be useful, if not essential.

We present an alternative approach to defining the Anthropocene as a formal geochronologic division of the GTS, proposing instead that the Anthropocene should be defined as a time-transgressive geological 'event': the aggregated effects of human activities that are transforming the Earth system and altering biodiversity, producing a substantial record in sedimentary strata and in human-modified ground. An event definition offers a resolution to many of the ongoing debates about the Anthropocene across disciplines, as it can characterize heterogeneous, multi-scalar, and socially differentiated processes and be empirically grounded in diachronous depositional records in ways that a formal
Anthropocene Series/Epoch definition never can. As a consequence, it also has the benefit of being more inclusive of a broad suite of diverse human practices that contribute to earth system processes. In these ways, an event definition will ultimately be more accurate, congruent with extant geological systematics, and useful to the wide range of disciplines that study human-environment interactions at a range of spatial and temporal scales. Importantly, an event designation would in no way diminish scientific assessment of the scope or magnitude of the most recent human transformations of Earth; rather it would place them with those of other biotically induced transformations of the Earth system (see below) that have been similarly characterized as events in the global geological record.

\section{Considering the Anthropocene as a Series/Epoch}

The primary difficulties in establishing an Anthropocene Series/ Epoch on the GTS are related to the requirements for its formalization. A unique basal boundary or GSSP (global boundary stratotype section and point), colloquially referred to as a 'golden spike,' is needed. A fundamental requirement of the definition of a GSSP is that it is marked by an internationally approved point in a rock, sediment or ice sequence, characterized by more than one biological, chemical and/or physical stratigraphic change in an accessible, continuous depositional sequence (Remane et al., 1996). Conceptually the boundary delineates deposits representing the same point in time worldwide.

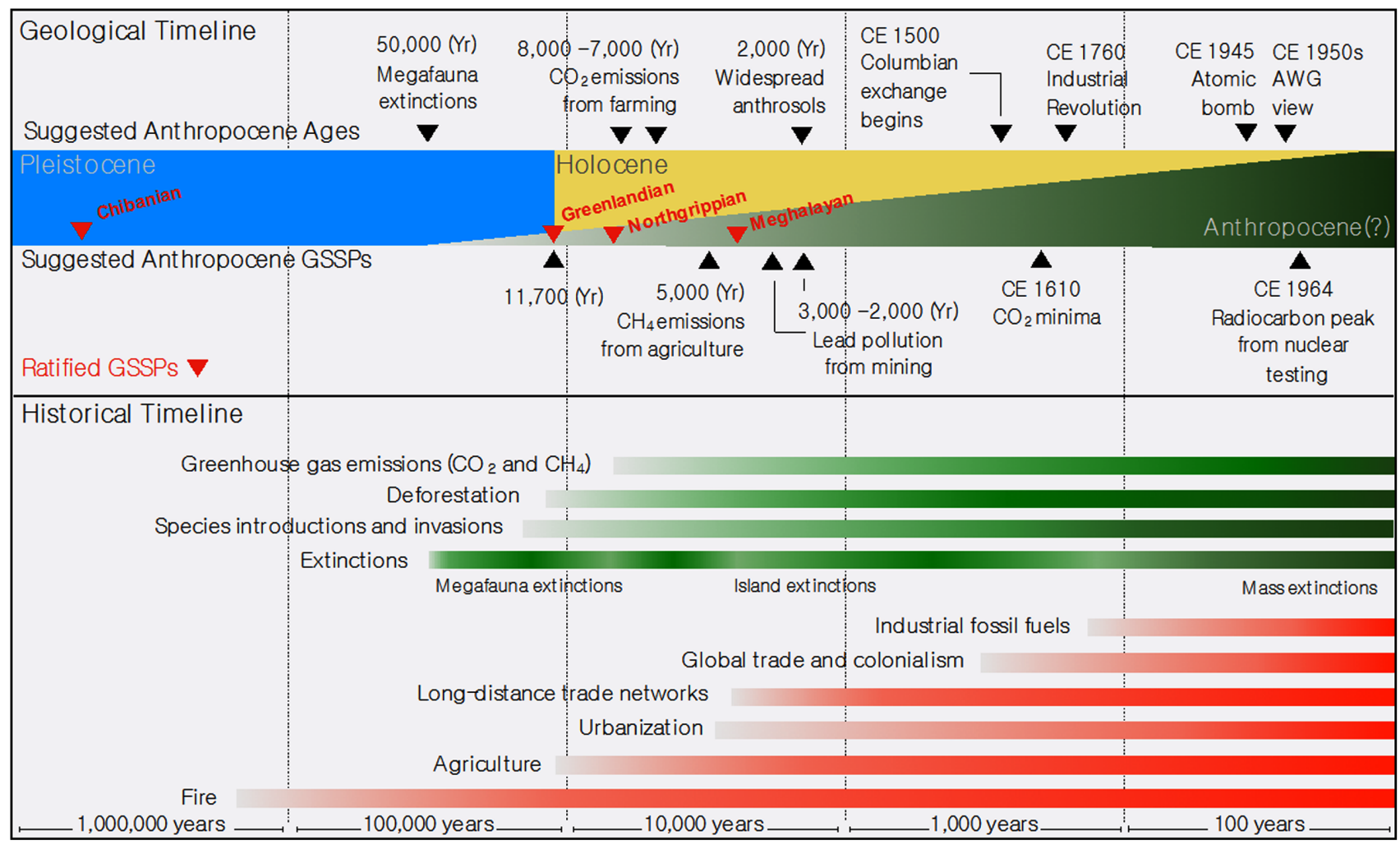

Figure 1. Geological Timeline (Top) compared to Historical Timeline (Bottom). Scholars have proposed a number of different starting dates for the Anthropocene that correspond to different social and environmental changes evident in the stratigraphic record. Rather than focusing on a single moment of transformation, an event framework would facilitate investigations of how human-environmental relationships and events of different scales and durations compound to produce global environmental change. Note that 'AWG view' refers to the Anthropocene Working Group 'Great Acceleration' proposal and that color densities broadly indicate the intensity of change. Figure developed from Ellis et al. (2016). 
However, an Anthropocene Series and Epoch defined in this way would necessarily consign significant evidence that attests to human modifications of the Earth's surface and systematic functioning to one side or the other of the agreed-upon boundary. If a GSSP were established to define the 'Anthropocene,' the term would then be divorced from the array of recent transformative impacts of human activities on the Earth system that are markedly time-transgressive when studied on human or historical timescales, such as the emergence of agriculture, industrialization, deforestation, and human-assisted species dispersals. Human-environment transformations that affect global processes began at different places at different times and spread geographically at different rates (Fig. 1). This is true whether the focus is on the earliest cultural practices to leave a signature on global environmental conditions thousands of years ago, the more recent effects of colonialism and industrialization, or accelerating contemporary transformations. Wherever a chronostratigraphic boundary is placed it will almost certainly exclude periods during which human activities have measurably influenced Earth's environmental processes and broader functioning, including the modification of landforms, reshaping ecosystems, contributing to mass extinctions, and affecting atmospheric conditions and global climate (e.g., Fyfe et al., 2015; Ruddiman et al., 2016; Brown et al., 2017; Roberts et al., 2021). Furthermore, the material remains and effects of prior human land use continue to exert influence on ecological and global atmospheric conditions today (e.g., Bauer and Ellis, 2018; Edgeworth, 2018). Although advocates of a mid- $20^{\text {th }}$ century start date for an Anthropocene Epoch emphasize that "the worldwide impact of the accelerating Industrial Revolution became both global and near-synchronous" at that time (Zalasiewicz et al., 2015), the isochronous constraints of an epoch-level designation preclude prior and, indeed, ongoing socio-environmental processes from inclusion in the Anthropocene interval. Because human impacts on the Earth's surface are diachronous, proposing an earlier start to an Anthropocene Epoch and a lower base to an Anthropocene Series, which defines it, is neither accurate nor practical.

\section{Defining and Conceptualizing Geological Events}

In contrast to the definition of a new Series/Epoch of the GTS, the designation of a geological event has no such formalization procedures nor GSSP requirements. Yet, to designate the Anthropocene as a geological event would not decrease its significance in Earth's history. In fact, it would place the Anthropocene with other great transformations of the Earth system. Consider the example of the Great Oxidation Event, which occurred roughly 2.4-2.1 billion years ago and demonstrates that humans are not the first organisms to contribute to a global transformation of Earth (Sagan, 2020). Before the Great Oxidation Event, Earth had a weakly reducing atmosphere in which oxidation was prevented. After cyanobacteria began to produce oxygen as the waste product of photosynthesis, atmospheric oxygen levels rose and radically changed the course of planetary development, including the evolution of multicellular life and the colonization of land following the development of an ozone layer (Schirrmeister et al., 2013). Despite its firm basis in stratigraphy (Buick, 2008; Eriksson and Cheney, 1992), the Great Oxidation Event is not used as part of the GTS but is recognized as a major transformative phase of the Earth system. The same is true for the Great Ordovician Biodiversification Event (GOBE), and for the continental invasion by land plants that transformed the Earth system and stratigraphic records during the Devonian Period (Le Hir et al., 2011; Dahl and Arens, 2020). These examples emphasize that geologic events are not points in time: they are significant happenings or occurrences that are heterogeneous over time and across the Earth.

In geology, event stratigraphy was first proposed by Ager (1973) for the recognition, study, and correlation of the effects of significant physical or biological events on the broader stratigraphic record, which is essentially composed of events. Geological events are both time-transgressive and multi-temporal; their extent can vary by orders of magnitude from seconds to millions of years and from local to global (Rawson et al., 2002).

The utility of an event paradigm for understanding the Anthropocene can be illustrated by its application to asynchronous events within the Quaternary Period. The division of Quaternary time has, from the mid-19th century, been based on the recognition of the succession of climatic events, principally glacial (cold) and interglacial (temperate) intervals. Highly-resolved stratigraphical sequences, such as those in ice cores and in some deep-ocean cores, provide evidence of much shorter term millennial-scale climatic events that are superimposed on the major glacial-interglacial cycles. Comparisons reveal that the North Atlantic events are not only out of phase with those of the Southern Hemisphere, but often display an 'opposite' climate signal (e.g., warm north; cold south), with a time-lag (diachroneity) between the climate shifts (Blunier et al., 1998; Steig and Alley, 2002; EPICA, 2006).

Social phenomena, such as trade networks, urbanization, and the development and adoption of new technologies, are socially heterogeneous and occur in different regions at markedly different times. In archaeology, depositional events interpreted from stratigraphic evidence may also be of multiple scales and durations, ranging from the dumping of a layer in seconds or minutes to the slow accumulation of occupational deposits over centuries. Shorter events may compound to produce stratigraphic events of longer duration. For example, the growth of urban settlements over millennia is often represented by bodies of strata tens of meters in thickness that result from the aggregation of numerous smaller depositional units - the traces of multiple events and processes of shorter duration. The time-transgressive and spatiotemporal heterogeneity of events are useful because scientific understanding of global environmental change requires analyses of processes at multiple temporal and spatial scales.

\section{Identifying the Diachroneity of Human-Envi- ronmental Change}

Defining the Anthropocene as a geological event allows it to be more closely connected with its diachronous stratigraphic evidence, which includes a wide range of deposits and paleoenvironmental proxies that attest to human transformations of environmental processes at local to global scales. While the geological version of event stratigraphy provides a useful framework for understanding the Anthropocene on the basis of its time-transgressive strata, it needs to be extended to encompass the many manifestations of human activity preserved within the stratigraphic record. 
One of the most obvious forms of evidence for diachronous anthropogenic impact across the globe is the distribution of human-modified ground that effectively forms a new surface stratum of the geosphere. This aggregate of human occupational deposits (e.g., earthworks, industrial spoil-heaps, concrete surfaces, etc.) and anthrosols (e.g., plaggen soils, terra preta, dark earth) has been termed the archaeosphere (Edgeworth, 2014, 2017, 2018), the human stratum, or the human stratal interval (Zalasiewicz, 2008), and greatly affects ecological conditions and even global albedo (Akbari et al., 2012). Although it has been treated as a singular entity in reference to the geosphere, archaeologists frequently emphasize its internal complexity (Harris, 1989), which includes multiple features, layers, cuts-and-fills (effectively human-made unconformities). These deposits are the product of interactions among humans and numerous other agencies - rivers, earthworms, soil bacteria, domesticated animals and plants - that influence their formation processes, precluding classification as strictly 'cultural' or 'natural' phenomena (Fig. 2). They also contain novel materials (e.g., ceramic, glass, metal alloys, plastics, concrete, etc.), artifacts, and structures. The remains of domesticated species tend to be present in large quantities, yet absent from earlier layers. As 'trace fossils' and biostratigraphic signatures of human activity, these can be used for correlation and dating purposes. However, they also serve as indicators of anthropogenic impact on landscape ecologies that in turn affect the Earth system.

Human transformations of geology go beyond the deposition of novel stratigraphic layers and can impact geophysical and geochemical processes across entire landscapes. Evidence from stream-valley alluviation and terrace formation have demonstrated that even seemingly 'natural' landforms and depositional processes are a complex prod- uct of human alterations of everything from changes in local base levels (e.g., from dams) to greatly increased sediment loads and rates of deposition associated with agriculture and land cover changes (Walter and Merritts, 2008; Brown et al., 2013). Numerous interdisciplinary case studies in recent decades reveal environmental phenomena-from landscape ecologies to landforms - previously recognized as 'natural' that are more accurately considered an outcome of human modifications with widescale and enduring effects (Wilkinson, 2003; Hect et al., 2014; Alizadeh et al., 2004; Bauer and Bhan, 2018).

Historical relationships between human and environmental processes can also be documented with paleoenvironmental proxies in sedimentary contexts, such as chemical signatures recorded in ice cores or speleothems, as well as floral and faunal remains in marine, fluvial, aeolian, colluvial or lacustrine deposits. Such depositional records can equally serve as a basis for identifying the diachronous effects of humans on local to global environmental processes. For example, the domestication of plants, human-assisted dispersal of domesticates and commensal species, and widespread deforestation in premodern periods is evident through the aggregation of hundreds of lacustrine pollen sequences that collectively demonstrate a reduction in forest taxa and an increase in non-arboreal or agricultural indicators across whole continents in a process that took place over millennia (e.g., Fyfe et al., 2015). Paleobotanical records can stand independently as evidence of human impacts (e.g., through the recognition of 'disturbance' taxa [Behre, 1981; Scharf, 2010]); however, these interpretations are strengthened when related to other forms of contextual data, such as independent archaeological evidence for the expansion of settlement or new land-use practices. For instance, floral and faunal remains

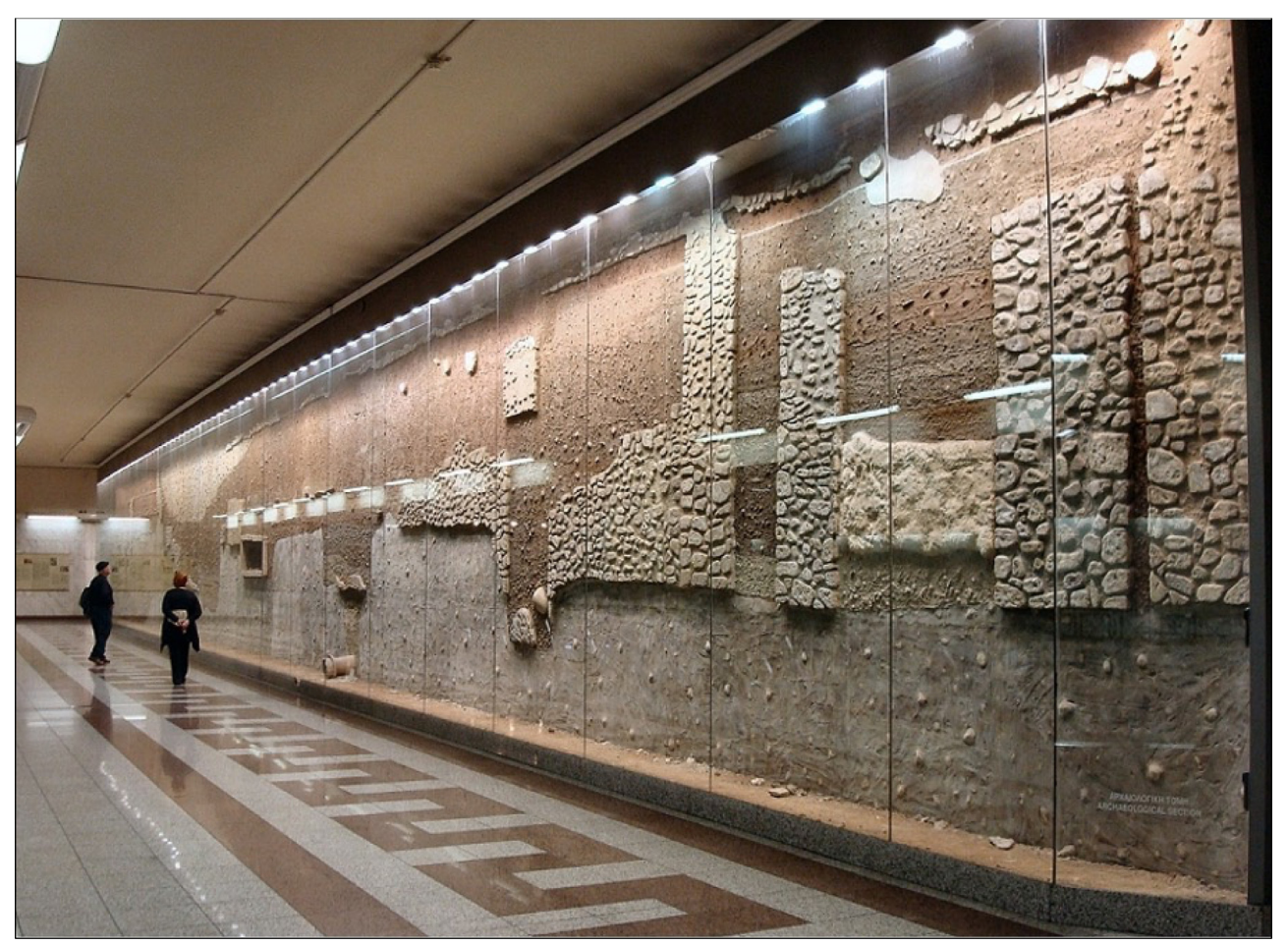

Figure 2. Example of human modified ground in section, as it was cut through during construction of the Syntagma Square metro station, Athens, and preserved in situ in the station concourse. Note how the section contains physical traces of many past events which have taken place over the last few thousand years—including the digging and backfilling of pits, the building of walls, the laying of floors and drains, and even the construction of the metro in the 1970s. Photograph by Hoverfish (2009), Wikimedia Commons, CC-BY-SA 3.0. 


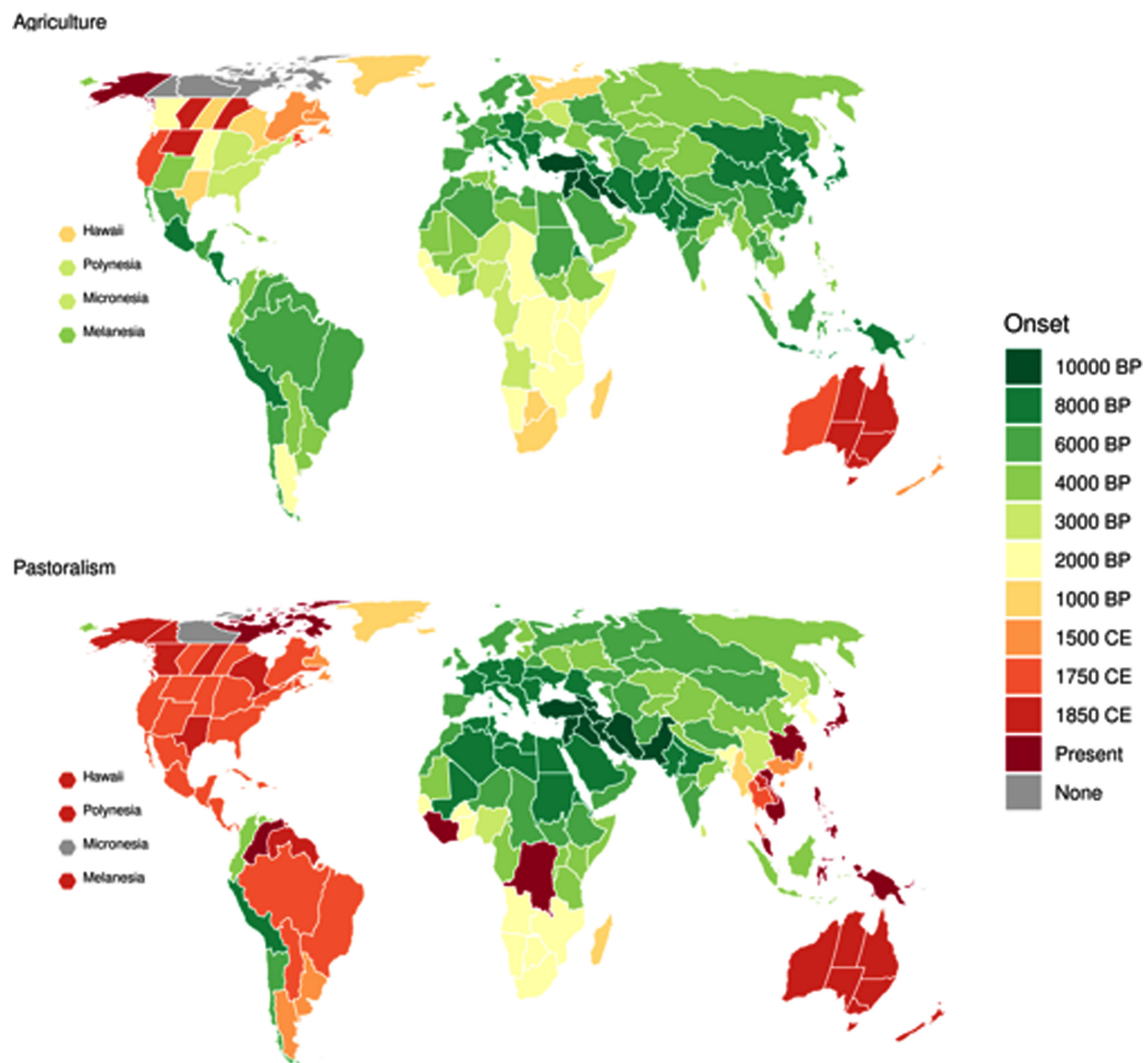

Figure 3. Regional onset of agricultural and pastoral activities according to the open-source ArchaeoGLOBE Project (Stephens et al. 2019). The figure illustrates the diachronous beginnings of some land-use practices that affected local ecologies and global atmospheric conditions.

in occupation layers of archaeological sites in Asia have allowed scholars to correlate the spread of methane-producing irrigated agriculture and cattle pastoralism during the Holocene with rises in atmospheric trace greenhouse gas concentrations that can be observed in ice cores, attesting to early human impacts on the global climate system (Fuller et al., 2011; Ruddiman et al., 2016) (Fig. 3).

\section{Multi-Scalar and Multi-Temporal Aspects of the Anthropocene Event}

Global to local scale manifestations of environmental and evolutionary changes are inter-connected and reflect interactions among 'systemic changes' to the Earth system and the 'cumulative changes' of localized events that aggregate to affect global conditions (Turner et al., 1990). An event approach to the Anthropocene would explicitly call attention to such multi-scalar interactions while also recognizing that various stratigraphic events may have different durations and temporal effects. For instance, manifestations of the Anthropocene Event over the last century, such as rapidly increasing global temperatures associated with the Great Acceleration (Steffen et al., 2007; Steffen et al., 2015; Zalasiewicz et al., 2019), are constituted through the compounding of multiple events and processes, including the transition to fossil fuels and new organizations of labor. Yet contemporary climate change is also influenced by the ongoing effects of much earlier land use, from large-scale deforestation to the thousands of water reservoirs constructed for herd animals and irrigated agriculture between 3000 and 500 years ago in South Asia that still contribute significantly to atmospheric methane today (Fuller et al., 2011; Bauer and Bhan, 2018).

The multi-scalar analyses enabled by an event paradigm also allow 
critical differences among social and environmental processes to be recognized, distinguished, and characterized. The isochronous global approach to defining the Anthropocene inevitably represents humans as a homogenous global force, thereby masking, conflating, and suppressing evidence of significant social differences and complexities that are obvious when viewed at other scales. Cultural and historical differences, socio-political divisions, and economic inequalities are expressed in the stratigraphic record at a variety of scales (e.g., households, communities, society, etc.). These differences are frequently manifest in different artifact assemblages and practices, which have differential impacts and vulnerabilities to environmental systems. These distinctions are generally lost or much obscured in attempts to develop a globally synchronous approach to the Anthropocene (Malm and Hornborg, 2014; Bonneuil and Fressoz, 2017; Bauer and Bhan, 2018; Yusoff, 2018). Reframing the Anthropocene as an event facilitates analytical attention on multiple social and historical processes and important differences among them while also encouraging a more integrative perspective on human transformations of environmental and evolutionary processes from local to global scales.

\section{Towards a Common Ground: Evolving the Anthro- pocene Paradigm}

The Anthropocene has emerged as an 'evolving paradigm' since it was first introduced more than 20 years ago (Butzer, 2015). Defining the Anthropocene as an Epoch in the GTS, starting globally in the 1950s, as proposed by the AWG, might provide a precise definition. However, there are many reasons why such a definition will only exacerbate disciplinary and conceptual confusion and conflict over the designation. Indeed, most current usage of the term 'Anthropocene' already applies to investigations of Earth history well before and after the middle of the $20^{\text {th }}$ century. This is the case partly because Crutzen's original definition emphasized the onset of European industrialization, the irreversible biological changes of domestication and the globalization of species and their accumulative impact on the global environment (Crutzen, 2002). Unsurprisingly many environmental scholars have thus used the Anthropocene designation to characterize socio-environmental relationships that significantly predate both the Industrial Revolution and the Great Acceleration (Doughty et al., 2010; Certini and Scalenghe, 2011; Smith and Zeder, 2013; Beach et al., 2015; Lewis and Maslin, 2015; Boivin et al., 2016; Wagreich and Draganits, 2018). Defining the Anthropocene as an event instead of an interval of geological time would effectively resolve many of the tensions among these different approaches, allowing investigations of human-environmental relationships at smaller-scales and different durations potentially to be related to past and ongoing global environmental changes. In this way, an Anthropocene Event designation would allow the concept to continue to function flexibly across disciplines (Braje and Lauer, 2020), while also establishing a common meaning and paradigm for essential interdisciplinary and multiscalar research.

An event paradigm would similarly alleviate some of the concerns about the designation Anthropocene in the social sciences and humanities, where scholars have advocated other critical terms (e.g., Capitalocene, Plantationocene, Thanatocene, Technocene, Chthulucene) to replace the Anthropocene (Haraway, 2015; Bonneuil and Fressoz, 2017), cautioned against Eurocentrism (Crossland, 2014; Morrison, 2015), and have been careful to stress cultural, class, gender and racial distinctions with respect to the concept (Bauer and Bhan 2018; Yusoff, 2018). While simply reframing the Anthropocene as an event will not resolve all the issues that these scholars have raised about its conception (e.g., Bauer and Bhan 2018), the explicit recognition of event multiplicity, diachroneity, and interconnections will enable far greater clarity on how various historical and social processes (e.g., urbanization, colonial violence, industrialization, capitalist production, etc.) are related to global environmental changes than would a 1950s Anthropocene Epoch definition.

Defining the Anthropocene as a geological event will not eliminate all the complications associated with formally rooting the event within the stratigraphic record. The Anthropocene Event should not be considered synonymous with human history. Even an event paradigm will not preclude strident scientific debate about when and how local or regional manifestations of human-environment interactions relate to globally consequential changes to Earth. Indeed, the recognition of an Anthropocene Event is only the first step in defining an interdisciplinary and multidisciplinary framework that will facilitate research in the years ahead, allowing future scholars to develop an understanding about how a range of multiscale, and socially and temporally differentiated processes, articulate, compound, or diverge in their transformation of the Earth system. In this way, an event designation will provide a more comprehensive, flexible, and broadly useful paradigm for formal definition of human impacts on Earth that fits both geological systematics and the sciences in general, while allowing for better resolution on the various social and cultural practices that influence Earth.

\section{Conclusion}

Current usage of the term 'Anthropocene' conceals a wide range of conflicting scientific meanings that has caused confusion among scholars and the broader public with whom they engage. This situation is unlikely to change without a more precise and useful definition. Yet, efforts to understand and address Earth's transformation through human social and cultural practices are fundamentally imperiled by continued efforts to define and formalize the Anthropocene as an official, rigidly constrained chronostratigraphic/ geochronologic interval in the GTS. A shift to a geological event framework is a solution that overcomes many of the problems with defining the Anthropocene. It eliminates ambiguity in the use of the term and offers a way forward through conceptual and disciplinary barriers by freeing the concept from the constraints of geological formalization, as well as from its alignment with established time units within the Holocene Series/Epoch. Moreover, an Anthropocene Event definition can be grounded on the substantial and widespread stratigraphic evidence of human-modified deposits and anthropogenic signals in the geological record, while formally acknowledging that Earth's unprecedented transformation by human activities has been a diachronous, heterogenous, and socially differentiated process. For these reasons, an event framework will also be more congruent with social science and humanities research that frequently stresses concerns over how historical processes related 
to social distinctions, such as those of culture, race, gender and class, have been obscured by efforts to define the Anthropocene as a Series/ Epoch. Acknowledging the Anthropocene as an event combines geological, ecological, and archaeological approaches and their respective scales of analysis, encouraging interdisciplinary collaboration along lines envisioned by others (Ellis et al., 2016; Horn and Bergthaller, 2019), in a field of research where scholars across the sciences can more productively work together using a common language.

\section{Acknowledgments}

Thanks are extended to Nicolas Gauthier for assistance in preparing Figure 3, and to Professor Angela Coe and several anonymous reviewers who helped improve the quality of this manuscript.

\section{References}

Ager, D.V., 1973, The Nature of the Stratigraphic Record. Wiley, New York, $151 \mathrm{p}$.

Akbari H., Matthews, H.D., and Steto D., 2012, The long-term effect of increasing the albedo of urban areas. Environmental Research Letters, v. 7, pp. 024004.

Alizadeh, A., Kouchoukos, N., Wilkinson, T.J., Bauer, A.m., and Mashkour, M., 2004, Human-environment interactions on the Upper Khuzestan Plains, Southwest Iran: recent investigations. Paleorient, v. 30, pp. 69-88.

Bauer, A.M., and Bhan, M., 2018, Climate Without Nature: A Critical Anthropology of the Anthropocene. Cambridge University Press, Cambridge, $186 \mathrm{p}$.

Bauer, A.M., and Ellis, E.C., 2018, The Anthropocene divide: obscuring understanding of social-environmental change. Current Anthropology, v. 59, pp. 209-227.

Beach, T., Luzzadder-Beach, S., Cook, D., Dunning, N., Kennett. J.D., Krause, S., Terry, R., Trein, D., and Valdez, F., 2015, Ancient Maya impacts on the earth's surface: an early anthropocene analog?. Quaternary Science Reviews, v. 124, pp. 1-30.

Behre, K.E., 1981, The interpretation of anthropogenic indicators in pollen diagrams. Pollen and Spores, v. 23, pp. 225-245.

Blunier, T., Chappellaz, J., Schwander, J., Dällenbach, A., Stauffer, B., Stocker, T.F., Raynaud, D., Jouzel, J., Clausen, H.B., Hammer, C.U., and Johnsen, S.J., 1998, Asynchrony of Antarctic and Greenland climate change during the last glacial period. Nature, v. 394, 739e 743.

Boivin, N.L., Zeder, M.A., Fuller, D.Q., Crowther, A., Larson, G., Erlandson, J.M., Denham, T., and Petraglia, M.D., 2016, Ecological consequences of human niche construction: Examining long-term anthropogenic shaping of global species distributions. Proceedings of the National Academy of Sciences, USA, v. 113, pp. 6388-6396.

Bonneuil, C., and Fressoz, J., 2017, The Shock of the Anthropocene. Verson, London, $320 \mathrm{p}$.

Braje, T.J., and Lauer, M., 2020, A meaningful Anthropocene?: golden spikes, transitions, boundary objects, and anthropogenic seascapes. Sustainability, v. 12, pp. 1-12.

Brown, A.G., Tooth, S., Bullard, J.E., Thomas, D.S.G., Chiverrell, R.C., Plater, A.J., Murton, J., Thorndycraft, V.R., Tarolli, P., Rose, J., Wainwright, J., Downs, P., and Aalto, R. 2017, The geomorphology of the Anthropocene: emergence, status and implications. Earth Surface Process and Landforms, v. 42, pp. 71-91.

Brown, A.G., Toms, P., Carey, C., and Rhodes, E., 2013, Geomorphology of the Anthropocene: time-transgressive discontinuities of humaninduced alluviation. Anthropocene, v. 1, pp. 3-13.
Buick, R., 2008, When did oxygenic photosynthesis evolve? Philosophical Transactions of the Royal Society B: Biological Sciences, v. 363, pp. 2731-2743.

Butzer, K., 2015, Anthropocene as an evolving paradigm. The Holocene, v. 25 , pp. 1539-1541.

Certini, G., and Scalenghe, R., 2011, Anthropogenic soils are the golden spikes for the Anthropocene. Holocene, v. 21, pp. 1269-1274.

Crossland, Z., 2014, Anthropocene: locating agency, imagining the future. Journal of Contemporary Archaeology, v. 1, pp. 123-128.

Crutzen, P.J., 2002, Geology of mankind. Nature, v. 415, p. 23.

Crutzen, P.J., and Stoermer, E.F., 2000, The 'Anthropocene'. IGBP Newsletter, v. 41, pp. 17-18.

Dahl, T.W., and Arens, S.K.M., 2020, The impacts of land plant evolution on Earth's climate and oxygenation state - An interdisciplinary review. Chemical Geology, v. 547, 119665.

Doughty, C.E., Wolf, A., and Field, C.B., 2010, Biophysical feedbacks between the Pleistocene megafauna extinction and climate: the first human-induced global warming? Geophysical Research Letters, v. 37, L15703.

Edgeworth, M., 2014, The relationship between archaeological stratigraphy and artificial ground and its significance in the Anthropocene. In: Waters, C.N., et al. (Eds.) A Stratigraphical Basis for the Anthropocene. Geological Society, London, pp. 91-108.

Edgeworth, M., 2017, Humanly modified ground. In: DellaSala, D.A., and Goldstein, M.I., The Encyclopedia of the Anthropocene. Elsevier, Oxford, pp. 157-161.

Edgeworth, M., Ellis, E.C., Gibbard, P., Neal, C., and Ellis, M., 2019, The chronostratigraphic method is unsuitable for defining the start of the Anthropocene. Progress in Physical Geography, v. 43, pp. 334-344.

Edgeworth, M., 2018, More than just a record: active ecological effects of archaeological strata. In: Torres de Souza, MA., and Costa, D.M. (Eds.), Historical Archaeology and Environment. Springer, Cham, pp. 19-40.

Ellis, E., Maslin, M., Boivin, N., and Bauer, A., 2016, Involve social scientists in defining the Anthropocene. Nature, v. 540, pp. 192-193.

EPICA, 2006. One-to-one coupling of glacial climate variability in Greenland and Antarctica. Nature, v. 444, pp. 195-198.

Eriksson, P.G., and Cheney, E.S., 1992, Evidence for the transition to an oxygen-rich atmosphere during the evolution of red beds in the lower Proterozoic sequences of southern Africa. Precambrian Research, v. 54, pp. 257-269.

Finney, S.C., and Edwards, L.E., 2016, The 'Anthropocene' epoch: scientific decision or political statement?. GSA Today, v. 26, pp. 4-10.

Fuller. D.Q., Etten, J.V., Manning., K., Castillo, C., Kingwell-Banham, E., Weisskopf, A., Qin, L., Sato, Y.I., and Hijmans. R.J., 2011, Contribution of rice agriculture and livestock pastoralism to prehistoric methane levels: An archaeological assessment. Holocene, v. 21, pp. 743-759.

Fyfe, R.M., Woodbridge, J., and Roberts, N., 2015, From forest to farmland: pollen? inferred land cover change across Europe using the pseudobiomization approach. Global Change Biology, v. 21, pp. 1197-1212.

Haraway, D., 2015, Anthropocene, Capitalocene, Plantationocene. Chthulucene: making kin. Environmental Humanities, v. 6, pp. 159-165.

Harris, E., 1989. Principles of Archaeological Stratigraphy. Academic Press, London, $136 \mathrm{p}$.

Hect, S.B., Morrison, K.D., and Padoch, C., 2014, The Social Lives of Forests: Past, Present, and Future of Woodland Resurgence. University of Chicago Press, Chicago, 512 p.

Horn, E., and Bergthaller, H., 2019, The Anthropocene: Key Issues for the Humanities. Routledge, London, $192 \mathrm{p}$.

Le Hir, G., Donnadieu, Y., Goddéris, Y., Meyer-Berthaud, B., Ramstein, G., and Blakey, C.R., 2011, The climate change caused by the land plant invasion in the Devonian. Earth and Planetary Science Letters, v. 310, pp. 203-212.

Lewis, S.L., and Maslin, M.A., 2015, Defining the Anthropocene. Nature, v. 519, pp. 171-180.

Lorimer, J., 2017, The Anthropo-scene: a guide for the perplexed. Social 
Studies of Science, v. 47, pp. 117-142.

Malm, A., and Hornborg, A., 2014, The geology of mankind? A critique of the Anthropocene narrative. The Anthropocene Review, v. 1, pp. 6269.

Morrison, K.D., 2015, Provincializing the Anthropocene. Seminar, v. 673, pp. $75-80$.

Remane, J., Bassett M.G., Cowie, J.W., Gohrbandt, K.H., Lane, H.R., Michelsen, O., Naiwen, W., and ICS members, 1996, Revised guidelines for the establishment of global chronostratigraphic standards by the International Commission on Stratigraphy (ICS), Episodes, v. 19, pp. 77-81.

Revkin, A.C., 2016, An Anthropocene Journey. Anthropocene Magazine, https://www.anthropocenemagazine.org/anthropocenejourney/

Roberts, P., Hamilton, R., and Piperno, D.R., 2021, Tropical forests as key sites of the "Anthropocene": Past and present perspectives. Proceedings of the National Academy of Sciences, USA, v. 118, doi:0.1073/pnas. 2109243118

Ruddiman, W.F., 2018, Three flaws in defining a formal 'Anthropocene.' Progress in Physical Geography, v. 42, pp. 451-461.

Ruddiman, W.F., Fuller, D.Q., Kutzbach, J.E., Tzedakis, P.C., Kaplan, J.O., Ellis, E.C., Vavrus, S.J., Roberts, C.N., Fyfe, R., He, F., Lemmen, C., and Woodbridge, J., 2016, Late Holocene climate: natural or anthropogenic? Review of Geophysics, v. 54, pp. 93-118.

Sagan, D., 2020, Gaia versus the Anthropocene: untimely thoughts on the current ecocatastrophe. Ecocene: Cappadocia Journal of Environmental Humanities, v. 1, pp. 137-146.

Scharf, E.A., 2010, Archaeology, land use, pollen and restoration in the Yazoo Basin (Mississippi, USA). Vegetation History and Archaeobotany, v. 19, pp. 159-175.

Schirrmeister, B.E., de Vos, J.M., Antonelli, A., and Bagheri, H.C., 2013, Evolution of multicellularity coincided with increased diversification of cyanobacteria and the Great Oxidation Event. Proceedings of the National Academy of Sciences, USA, v. 110, pp. 1791-1796.

Smith, B.D., and Zeder, M.A., 2013, The onset of the Anthropocene. Anthropocene, v. 4, pp. 8-13.

Steffen, W., Crutzen, P.J., and McNeill, J.R., 2007, The Anthropocene: are humans now overwhelming the great forces of nature? Ambio, v. 36, pp. 614-621.

Steffen, W., Broadgate, W., Deutsch, L., Gaffney, O., and Ludwig, C., 2015, The trajectory of the Anthropocene: The Great Acceleration. Anthropocene Review, v. 2, pp. 81-98.

Steig, E.J., and Alley, R.B., 2002, Phase relationships between Antarctic and Greenland climate records. Annals of Glaciology, v. 35, pp. 451456.

Stephens, L., Fuller, D., Boivin, N., Rick, T., Gauthier, N., Kay, A., Marwick, B., Armstrong, C.G., Barton, C.M., Denham, T., Douglass, K., Driver, J., Janz, L., Roberts, P., Rogers, J.D., Thakar, H., Altaweel, M., Johnson, A.L., Sampietro Vattuone, M.M., Aldenderfer, M., Archila, S., Artioli, G., Bale, M.T., Beach, T., Borrell, F., Braje, T., Buckland, P.I., Jiménez Cano, N.G., Capriles, J.M., Diez Castillo, A., Çilingiroğlu Ç, Negus Cleary, M., Conolly, J., Coutros, P.R., Covey, R.A., Cremaschi, M., Crowther, A., Der L, di Lernia, S., Doershuk, J.F., Doolittle, W.E., Edwards, K.J., Erlandson, J.M., Evans, D., Fairbairn, A., Faulkner, P., Feinman, G., Fernandes, R., Fitzpatrick, S.M., Fyfe, R., Garcea, E., Goldstein, S., Goodman, R.C., Dalpoim Guedes, J., Herrmann, J., Hiscock, P., Hommel, P., Horsburgh, K.A., Hritz, C., Ives, J.W., Junno, A., Kahn, J.G., Kaufman, B., Kearns, C., Kidder, T.R., Lano, F., Lawrence, D., Lee, G.A., Levin, M.J., Lindskoug, H.B., López-Sáez, J.A., Macrae, S., Marchant, R., Marston, J.M., McClure, S., McCoy, M.D., Miller, A.V., Morrison, M., Motuzaite Matuzeviciute, G., Müller, J., Nayak, A., Noerwidi, S., Peres, T.M., Peterson, C.E., Proctor, L., Randall, A.R., Renette, S., Robbins Schug, G., Ryze- wski, K., Saini, R., Scheinsohn, V., Schmidt, P., Sebillaud, P., Seitsonen, O., Simpson, I.A., Soltysiak, A., Speakman, R.J., Spengler, R.N., Steffen, M.L., Storozum, M.J., Strickland, K.M., Thompson, J., Thurston, T.L., Ulm, S., Ustunkaya, M.C., Welker, M.H., West, C., Williams, P.R., Wright, D.K., Wright, N., Zahir, M., Zerboni, A., Beaudoin, E., Munevar Garcia, S., Powell, J., Thornton, A., Kaplan, J.O., Gaillard, M.J., Klein Goldewijk, K., and Ellis, E., 2019, Archaeological assessment reveals Earth's early transformation through land use. Science, v. 365, pp. 897-902.

Syvitski, J., Waters, C.N., Day, J., Milliman, J.D., Summerhayes, C., Steffen, W., Zalasiewicz, J., Cearreta, A., Gałuszka, A., Hajdas, I., Head, M.J., Leinfelder, R., McNeill, J.R., Poirier, C., Rose, N.L., Shotyk, W., Wagreich, M., and Williams, M., 2020, Extraordinary human energy consumption and resultant geological impacts beginning around 1950 $\mathrm{CE}$ initiated the proposed Anthropocene Epoch. Communications Earth and Environment, v. 1, doi:10.1038/s43247-020-00029-y

Turner, B.L., Kasperson, R.E., Meyer, W.B., Dow, K.M., Golding, D., Kasperson, J.X. Mitchell, R.C., and Ratick, S.J., 1990, Two types of global environmental change: definitional and spatial-scale issues in their human dimensions. Global Environmental Change, v. 1, pp. 14-22.

Wagreich, M., and Draganits, E., 2018, Early mining and smelting lead anomalies in geological archives as potential stratigraphic markers for the base of an early Anthropocene. Anthropocene Review, v. 5, pp. 177-201.

Walker, M.J.C., Berkelhammer, M., Bjorck, S., Cwynar, L.C., Fisher, D.A., Long, A.J., Lowe, J.J., Newnham, R.M., Rasmussen, S.O., and Weiss, H., 2019, Formal subdivision of the Holocene Series/Epoch: A Summary. Journal of the Geological Society of India, v. 93, pp. 135141.

Walter, R.C., and Merritts, D.J., 2008, Natural streams and the legacy of water-powered mills. Science, v. 319, pp. 299-304.

Waters, C.N., Zalasiewicz, J., Summerhayes, C., Barnosky, A.D., Poirier, C., Gałuszka, A., Cearreta, A., Edgeworth, M., Ellis, E.C., Ellis,M., Jeandel, C., Leinfelder, R., McNeill, J. R., De Richter, D., Steffen, W., Syvitski, J., Vidas, D., Wagreich, M., Williams, M., Zhisheng, A., Grinevald, J., Odada, E., Oreskes, N., and Wolfe, A.P., 2016, The Anthropocene is functionally and stratigraphically distinct from the Holocene. Science, v. 351, aad2622.

Yusoff, K., 2018, A Billion Black Anthropocenes or None. University of Minnesota Press, Minneapolis, $130 \mathrm{p}$.

Zalasiewicz, J., 2008, The Earth After Us: What Legacy Will Humans Leave in the Rocks? Oxford University Press, Oxford, $256 \mathrm{p}$.

Zalasiewicz, J., Waters, C.N., Williams, M., Barnosky, A.D., Cearreta, A., Crutzen, P., Ellis, E., Ellis, M.A., Fairchild, I.J., Grinevald, J., Haff, P.K., Hajdas, I., Leinfelder, R., McNeill, J., Odada, E.O., Poirier, C., Richter, D., Steffen, W., Summerhayes, C., Syvitski, J.P.M., Vidas, D., Wagreich, M., Wing, S.L., Wolfe, A.P., An, Z., Oreskes, N., 2015, When did the Anthropocene begin? A mid-twentieth century boundary level is stratigraphically optimal. Quaternary International, v. 383, pp. 196-203.

Zalasiewicz, J., Waters, C.N., Ellis, E.C., Head, M.J., Vidas, D., Steffen, W., Thomas, J.A., Horn, E., Summerhayes, C.P., Leinfelder, R., McNeill, J.R., Gałuszka, A., Williams, M., Barnosky, A.D., Richter, D., Gibbard, P.L., Syvitski, J., Jeandel, C., Cearreta, A., Cundy, A.B., Fairchild, I.J., Rose, N.L., Sul, J.A.I, Shotyk, W., Turner, S., Wagreich, M., and Zinke, J., 2021, The Anthropocene: Comparing its meaning in geology (chronostratigraphy) with conceptual approaches arising in other disciplines. Earth's Future, v. 9, e2020EF001896.

Zalasiewicz, J., Waters, C.N., Williams, M., and Summerhayes, C., 2019, The Anthropocene as a Geological Time Unit: A Guide to the Scientific Evidence and Current Debate. Cambridge University Press, Cambridge, $385 \mathrm{p}$. 


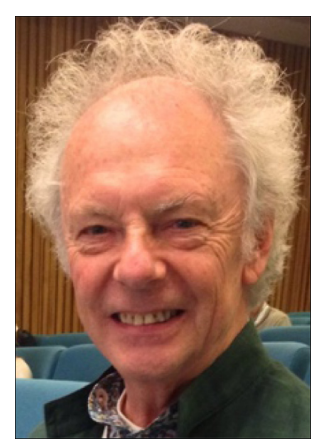

Philip Gibbard is Emeritus Professor of Quaternary Palaeoenvironments in the University of Cambridge, and Dosent in the University of Helsinki. He took his BSc in Geology at the University of Sheffield and his $\mathrm{PhD}$ in the University of Cambridge. He is past-chair of the International Subcommission on Quaternary Stratigraphy and is Secretary General of the International Commission on Stratigraphy. He chaired the INQUA Stratigraphy and Geochronology Commission, is a member of the INQUA Subcommission of European Quaternary Stratigraphy and the Geological Society's Stratigraphy Commission. His research is focused on Quaternary and Neogene terrestrial and shallow marine stratigraphy and palaeoenvironmental reconstruction.

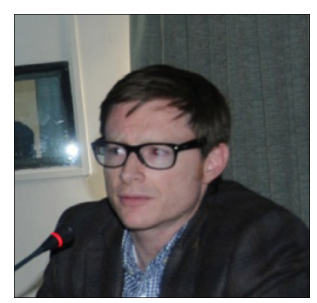

Andrew Bauer is Associate Professor in the Department of Anthropology at Stanford University, where his research broadly focuses on the archaeology of human-environment relations. Bauer's primary fieldwork is based in southern India. His research interests include geoarchaeology, paleoecology, and social vulnerabilities to climate change.

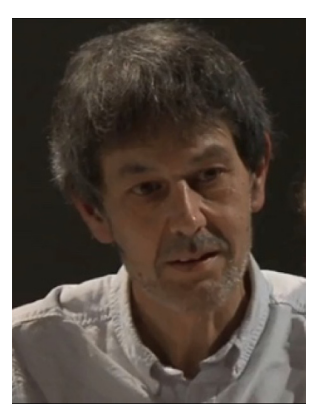

Matt Edgeworth is Honorary Visiting Fellow in the school of Archaeology and Ancient History at the University of Leicester, UK. He works as field archaeologist in a commercial environment, excavating sites of a wide range of different periods. Current research interests include urban stratigraphy, archaeology of rivers, and ecological aspects of archaeological evidence. 